\title{
Induction of Sulfated Polysaccharides in Spirulina platensis as Response to Nitrogen Concentration and its Biological Evaluation
}

Abd EI Baky H, Hanaa EI Baz KF and EL-Latife SA

Plant Biochemistry Department, National Research Centre, Dokki, Cairo, Egypt

\begin{abstract}
Sulfated polysaccharides (SPS) extracted with hot water from Spirulina grown on nutrient medium containing $412 \mathrm{ppm}$ (optimal $\mathrm{N}_{2}$ level) and $45 \mathrm{ppm}$ (limited $\mathrm{N}_{2}$ level) ppm nitrogen were found to be rich in sulfate contents with values $5.02 \%$ and $4.13 \%$ ), respectively. Monosaccharides content of SPS in both algae cells were analyzed by HPLC and the results showed that: glucouronic acid and galactose were the predominating sugar in all extracts, followed by rhamnose, arabinose, glucose and ribose. The SPS analyzed by FT-IR spectra showed an intense band of absorption at 790-850 $\mathrm{cm}^{-1}$ indicating the presence of sulfate group of polysaccharides. SPS of S. platensis exhibited anticoagulant activities as compared with heparin (standard anticoagulant drug). SPS showed a significant growth inhibit (\%) against HepG2 and MCF7 cancer cell lines, with $I_{50}$ value ranged between 4.0 and $0.54 \mathrm{~g} / \mathrm{ml}$. SPS showed antiviral activity against HSV-1 (standard strain) as a model of DNA virus (as assessed by a plaque reduction test and antioxidant activities toward $\mathrm{DPPH}$. and $\mathrm{ABTS}{ }^{+}{ }^{+}$radical.
\end{abstract}

Keywords: Spirulina platensis; Sulfated Polysaccharide; Blue Green Microalgae

\section{Introduction}

Spirulina has a high nutritional value due to its content of a wide range of essential nutrients, such as provitamin, minerals, proteins, polyunsaturated fatty acids such as gamma linolenic acid and sulfated polysaccharides $[1,2]$. In the last decades, high attention has focused on the biological properties of polysaccharides and their chemical derivatives, especially sulfated derivatives. Sulfated polysaccharides have a broad range of important bioactivities comprising antioxidant, anticoagulant and antithrombotic activities. They are also known to increase the resistance to some virus and inhibit some tumor development [3]. Sulfated polysaccharides comprise a complex group of macromolecules with a wide range of important biological properties. These anionic polymers are widespread in nature, occurring in a great variety of organisms [4].

Sulfated polysaccharides (SPS) are widespread in nature, especially occurring in marine algae. Many seaweed polysaccharides, such as agar and carrageenan, are used extensively in industry. Recently, there has been an increasing interest in systematic screening of biological activity of sulfated polysaccharides isolated from marine algae. The biological features of the SP reported till now are antioxidant, antitumor, immunomodulatory, inflammation, anticoagulant, antiviral, antiprotozoan, antibacterial, antilipemic.

Some of them have been developed as new drugs for antitumor, antivirus, anticoagulant and antihyperlipidemia treatment. These SPS have linear structures and possess many biological activities such as antivirus and antitumor activities. However, there is no report about the application of the SPS in the inhibition of urinary stones [5]. Calcium spirulan (Ca-SP) is a novel sulfated polysaccharide isolated from a hot water extract of a blue-green alga Spirulina platensis [6]. Hayakawa et al. [7] reported that calcium spirulan, showed an inhibitory effect on the replication of enveloped viruses. Recently Ca-SP is a potent inhibitor of thrombin through heparin cofactor II HC II, and that Ca-SP is a sulfated polysaccharide distinct from heparin or dermatan sulfate in an experiment of chondroitinase treatment.

The aim of the present work was to produce Spirulina platensis with a high content of sulfated polysaccharides and evaluate their biological activities as anticoagulant, anticancer, antiviral, antimicrobial, and antioxidant.

\section{Materials and Methods}

\section{Algal source}

The blue green algae, Spirulina platensis was obtained from the Culture Collection of Texas University, Austin, Texas, USA.

\section{Growth conditions}

Algae were cultured in $4 \mathrm{~L}$ Erlenmeyer flasks containing autoclaved 3 L Zarrouk's medium [8]. The medium was enriched with nitrogen (as sodium nitrate) at concentrations of 45, 128, 293, 412 (optimum concentration usually use) and $622 \mathrm{ppm}$. The $\mathrm{pH}$ of all media was adjusted to 10.5 and the medium autoclaved. The cultures were gassed with $0.3 \% \mathrm{CO}_{2}$ in air and the algae were cultivated at $25 \pm 3^{\circ} \mathrm{C}$. The cultivated flasks were illuminated $24 \mathrm{~h}$ with continuous cool white fluorescent lamps at $400 \mathrm{~W}$ (equal $477 \mathrm{~lx}$ ) $[9,10]$.

\section{Growth measurements and harvesting}

The growth rate of Spirulina platensis was monitoring every three days through cultivation period by determining the dry weight (d. w) and optical density at $670 \mathrm{~nm}$ methods Payer [11]. The cells were harvested at the stationary phase, by centrifugation at $10,000 \mathrm{~g}\left(4^{\circ} \mathrm{C}\right)$ for $15 \mathrm{~min}$ and the cells masses were stored at $-20^{\circ} \mathrm{C}$ until analysis.

*Corresponding author: Abd El Baky, Plant Biochemistry Department National Research Centre, Dokki, Cairo, Egypt, Tel: 202 3377164; E-mail: abdelbakyh@hotmail.com

Received September 05, 2013; Accepted November 28, 2013; Published December 04, 2013

Citation: Abd El Baky H, Hanaa El Baz KF, EL-Latife SA (2013) Induction of Sulfated Polysaccharides in Spirulina platensis as Response to Nitrogen Concentration and its Biological Evaluation J Aquac Res Development 5: 206 doi:10.4172/2155-9546.1000206

Copyright: @ 2013 Abd El Baky H, et al. This is an open-access article distributed under the terms of the Creative Commons Attribution License, which permits unrestricted use, distribution, and reproduction in any medium, provided the original author and source are credited. 
Citation: Abd El Baky H, Hanaa El Baz KF, EL-Latife SA (2013) Induction of Sulfated Polysaccharides in Spirulina platensis as Response to Nitrogen Concentration and its Biological Evaluation. J Aquac Res Development 5: 206 doi:10.4172/2155-9546.1000206

Page 2 of 8

\section{Extraction of sulfated polysaccharides from Spirulina platensis}

The sulfated polysaccharide was extracted from S. platensis, using two different extraction methods:

Extraction of sulfated polysaccharides with hot water: Fresh algae $(5 \mathrm{~g})$ were mixed with $20 \mathrm{ml}$ of distilled water transfer to water bath at $100^{\circ} \mathrm{C}$ for $2 \mathrm{~h}$, and the liquid was then filtered through Whatman filter paper No.54. Sulfated polysaccharides were then precipitated using ethanol absolute and centrifuged at $10,000 \mathrm{rpm}$ to pool it and evaporated under vacuum at $60^{\circ} \mathrm{C}$ in rotary evaporator according to Asker et al. [12]. The precipitate was dried at $30^{\circ} \mathrm{C}$, to yield brownish powder crude sulfated polysaccharides [13] and kept for analysis.

Extraction of sulfated polysaccharides with ethanol 85\%: Sulfated polysaccharides of fresh algae $(5 \mathrm{~g})$ was extracted with ethanol $85 \%$, transfer to water bath at $80^{\circ} \mathrm{C}$ for $2 \mathrm{~h}$, the liquid was then evaporated under vacuum at $60^{\circ} \mathrm{C}$, and kept for analysis according to Pugh et al. [14] and Yim et al. [15].

\section{Determination of total carbohydrates, reducing sugars and Non- reducing sugars of algal sulfated polysaccharides}

Total carbohydrates were estimated by phenol /sulfuric acid reagent using the method of Dubois et al. [16], while reducing sugars was determined by the dinitrosalicylic acid (DNS) using the method of Miller et al. [17]. Non- reducing sugars were calculated by difference between the total carbohydrates and the reducing sugars.

\section{Determination of Sulfate content algal polysaccharides}

Sulfate content in algal extracts was determined after hydrolysis with $1 \mathrm{~N} \mathrm{HCl}$ at $100^{\circ} \mathrm{C}$ for $1 \mathrm{~h}$ using sodium-rhodizo-nate method, described by [18] as followed: $0.5 \mathrm{ml}$ of each samples and water were pipetted into test tubes and $2.0 \mathrm{ml}$ ethanol absolute was added. If precipitation occurs the tubes were centrifuged until clear. $1.0 \mathrm{ml} \mathrm{BaCl}$ buffer and $1.5 \mathrm{ml}$ sodium rhodizo-nate solution were pipetted in and then the tubes were well shaken, and were allowed to stand for $10 \mathrm{~min}$ in the dark at room temperature. The intensity of the color was measured spectrophotometrically at $520 \mathrm{~nm}$. The color remains unchanged for 30 min. A standard $\left(\mathrm{Na}_{2} \mathrm{SO}_{4}\right)$ series were treated as the samples.

\section{Determination of monosaccharides content of algal polysaccharides by HPLC}

The monosaccharides in the extract of the higher sulfate content was quantified by HPLC on Shimadzu Shim-Pack SCR-101N column $(7.9 \mathrm{~mm} \times 30 \mathrm{~cm})$, using deionized water as the mobile phase (flow rate $0.5 \mathrm{ml} / \mathrm{min}$ ) and refractive index detector, as described by El-Sayed et al. [19].

\section{Infrared spectroscopic measurements analysis of algal sulfated polysaccharides}

The higher extracts in sulfate content were mixed with $\mathrm{KBr}$, grounded and pressed into a $1 \mathrm{~mm}$ pellet. IR spectra of samples were recorded on JASCO FT/IR 6100A spectrometer [12].

\section{Biological evaluation of Spriulna sulfated polysaccharide}

Antimicrobial activity of sulfated polysaccharide: The following organisms were obtained from Northern Regional Research Laboratory (NRRL), USA: Bucillus subtiles NRRL B-543 (Gram (+), Escherichia coli NRRL B-210 (Gram (-), Aspergillus niger NRRL 599 and Candida albicans NRRL Y-477. The sterilized nutrient agar medium "50 ml" was prepared by the method of [20]. An amount from the test solution (0.1 $\mathrm{ml}$ dissolved in ethanol) was poured inside the holes. Three holes were made for each sample to be assayed. The Petri dishes were incubated at $6^{\circ} \mathrm{C}$ for $3 \mathrm{~h}$. to permit good diffusion and then transferred to an incubator of $28^{\circ} \mathrm{C}$ for $16 \mathrm{~h}$. The diameter of the clear inhibition zone was measured for each sample. Due to the nature of the extracts under investigation serial dilutions of the sample in dimethylsulphoxide (DMSO) were prepared dilutions from 1: 10 to 1: $100 \mathrm{v} / \mathrm{v}$.

After complete mixing, $0.1 \mathrm{ml}$ of each diluted solution was separately tested for its activity against the test organisms. The Minimum Inhibitory Concentration (MIC) was recorded for SPS extracted with hot water from Spirulina grown on medium containing $350 \mathrm{mg} / \mathrm{L}$ sulfur as the minimum level preventing growth of Candida albicans and Aspergillus niger after $24 \mathrm{~h}$ [21].

Antiviral activity of Spriulna sulfated polysaccharides: Preparation of samples for antiviral bioassay: Spriulna sulfated polysaccharides were dissolved as $100 \mathrm{mg}$ each in $1 \mathrm{ml}$ of $0.1 \mathrm{M}$ phosphate buffer ( $\mathrm{pH}$ 7). The final concentration was $100 \mathrm{~g} / \mathrm{ml}$ (Stock solution).

Viruses used: Herpes simplex virus type 1 (HSV-1) and Hepatitis A virus (cell culture adapted strain MBB). The virus was obtained from virology laboratory, NRC, Giza, Egypt. Viruses were propagated and titrated on Vero cell (HSV-1) strain.

Plaque infectivity reduction assay: The method described by Silva et al. [22] was used where, a 6-well plate was cultivated with Vero cell (HSV) and another plate containing HepG2 (HAV) culture (105cell/ml) and incubated for 2 days at $37^{\circ} \mathrm{C}$. Virus was diluted to give $107 \mathrm{PFU} / \mathrm{ml}$ as final concentrations and mixed with the algal extract at the previous concentration and incubated overnight at $4^{\circ} \mathrm{C}$. Growth medium was removed from the multiwell plate and virus-compound mixture was inoculated $(100 \mu \mathrm{l} /$ well $)$. After contact time, inoculate were aspirated, agarose were overlaid, and plates were left to solidify then incubated until the development of virus plaques. Cell sheets were fixed in $10 \%$ formalin and stained with crystal violet stain.

Anticoagulant activity of $S$. platensis. sulfated polysaccharides: To $0.8 \mathrm{ml}$ of the extract solution (1\%), and $0.8 \mathrm{ml}$ of standard heparin sodium solution (0.5 U.S.P. unit / $0.8 \mathrm{ml}$ ) was as positive control, or $0.8 \mathrm{ml}$ saline solution as negative control was added these mixture in the test tube. Then, $1 \mathrm{ml}$ rat plasma and $0.2 \mathrm{ml}$ of $1 \%$ calcium chloride solution were added to each tube. Tubes were stopped immediately and the time was recorded, and inverting three times in such a way mixed the contents that the entire inner surface of the tube was wet. The time required for clotting was determined [23].

\section{Antioxidant activity of $S$. platensis sulfated polysaccharides:}

DPPH. scavenging radical assay: The antioxidant activity of sulfated polysaccharides extracts were determined based on DPPH. radical described by Ye et al. [24]. A $0.1 \mathrm{mM}$ of ethanolic DPPH solution was prepared. The initial absorbance of the DPPH in ethanol was measured at $517 \mathrm{~nm}$ and did not change throughout the period of assay. An aliquot $(0.1 \mathrm{ml})$ of each sample (with appropriate dilution if necessary) was added to $3.0 \mathrm{ml}$ of ethanolic DPPH solution. Discolorations were measured at $517 \mathrm{~nm}$ after incubation for $30 \mathrm{~min}$ in the dark. Measurements were performed at least in triplicate. The percentage of DPPH which was scavenged was calculated using the following equation:

Scavenging\% $=[1-($ A sample - A blank/A control $)] \times 100 \%$ 
Citation: Abd El Baky H, Hanaa El Baz KF, EL-Latife SA (2013) Induction of Sulfated Polysaccharides in Spirulina platensis as Response to Nitrogen Concentration and its Biological Evaluation. J Aquac Res Development 5: 206 doi:10.4172/2155-9546.1000206

Page 3 of 8

Where, ethanol $(3.0 \mathrm{ml})$ plus sample solution $(0.1 \mathrm{ml})$ was used as a blank and $3 \mathrm{ml}$ of DPPH-ethanol solution plus ethanol $(0.1 \mathrm{ml})$ was also used as a negative control.

ABTS scavenging radical assay: TBAS radical scavenging activity of the SPS was determined according to the method of Urbani et al. [25] with some modifications as follows: $\mathrm{ABTS}^{+}$was produced by reacting $7 \mathrm{mM}$ ABTS aqueous solution with $2.4 \mathrm{mM}$ potassium persulfate in the dark for $12-16 \mathrm{~h}$ at room temperature. Prior to assay, this solution was diluted in ethanol (about $1: 89 \mathrm{v} / \mathrm{v}$ ) and equilibrated at $30^{\circ} \mathrm{C}$ to give an absorbance at $734 \mathrm{~nm}$ of $0.700 \pm 0.02$. After the addition of $1 \mathrm{ml}$ of diluted ABTS solution to $10 \mu$ of test sample in ethanol, absorbance was measured at $30^{\circ} \mathrm{C}$ exactly $30 \mathrm{~min}$ after the initial mixing. The inhibition percentage was calculated for the blank absorbance at $734 \mathrm{~nm}$. Radical scavenging activity was expressed as the inhibition percentage of free radical by the sample and was calculated using the formula: \% ABTS radical scavenging activity $=($ control $\mathrm{OD}$-sample $\mathrm{OD} /$ control $\mathrm{OD})$ $\times 100$.

\section{Anticancer activity of microalgal sulfated polysaccharides}

Cytotoxicity activity Skehan et al. [26] of hot water and ethanol extracts which contain the highest sulfate content was tested on two cell lines, HepG2 (liver carcinoma cell line) and MCF7 (breast carcinoma cell line). The relation between surviving fraction and drug concentration is plotted to get the survival curve of each tumor cell line after the specified compound.

\section{Statistical analysis}

All experiments were performed in triplicate $(n=3)$ and results were expressed as mean \pm SD (standard deviation). Statistical analysis was carried out with (SPSS package version 10.0 MERANT, USA). Multiple comparisons of means were done by LSD (Least significance difference) at significance level $\mathrm{p} \leq 0.05$.

\section{Results and Discussion}

\section{Effect of nitrogen concentrations on growth rate of Spirulina platensis}

The effect of different nitrogen concentrations on growth of $S$. Platensis grown for 12 days cultures are shown in Figure 1. It's clear that the growth of Spirulina was increased gradually with culture age and reached the maximum $(3.186 \mathrm{~g} / \mathrm{L})$ at 12 days of culture age and when the concentration of $412 \mathrm{ppm}$ nitrogen was applied in the culture. Fabregas et al. [27]; Gordillo et al. [28]; Vermaas W.F.[29] and Colla et al. (2) mentioned that, in micro algal species, the concentration of

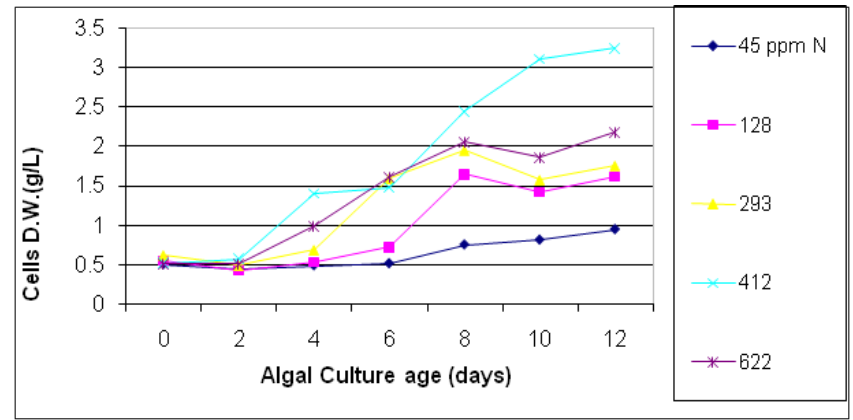

Figure 1: Spirulina platensis grown at different nitrogen concentrations growth rate. photosynthetic pigments in the culture increases while nitrogen is the limiting factor of growth.

Effect of nitrogen concentrations on total carbohydrate, reducing and non- reducing sugars $\%$ of $S$. platensis

Total carbohydrate \%, reducing and non- reducing sugars are different algal cells shown in (Table 1). The total carbohydrate, reducing and non-reducing sugars content reached the maximum $(31.05,2.28$, $28.77 \%$ respectively) when the concentration of nitrogen was $45 \mathrm{ppm}$ in the culture. In the present study, the results mentioned above indicate that high concentration of nitrogen source supported the biomass concentration in contrast to the carbohydrate content. The decreased growth pattern in S. platensis under nitrogen deficient conditions. Fabregas et al. [27] observed that, the production of exopolysaccharide is inversely related to the amount of nitrogen available. According to Yeesang and Cheirsilp [30], under nitrogen deficient conditions, algal cells accumulate carbon metabolites as carbohydrate [30]. It has earlier been reported that under nitrogen starvation conditions, nitrogen containing macromolecules and carbon reserve compounds like carbohydrates and fats are accumulated.

Effect of nitrogen concentrations on accumulation sulfated polysaccharide extracted with hot water and ethanol $85 \%$

As shown in Table 2, sulfated polysaccharide extracted with hot water from S. Platensis grown on medium containing $412 \mathrm{ppm}$ nitrogen, showed the higher value of \% total carbohydrate $(17.8 \%)$. These result suggested that in the growth medium, algae cells start to store carbohydrate to use them on energy production. While, sulfated polysaccharide extracted with hot water from S. Platensis grown on medium containing $293 \mathrm{ppm}$ nitrogen showed the maximum

\begin{tabular}{|c|c|c|c|}
\hline $\begin{array}{c}\text { Nitrogen } \\
\text { Concentrations (ppm) }\end{array}$ & $\begin{array}{c}\text { Total } \\
\text { carbohydrate } \%\end{array}$ & $\begin{array}{c}\text { Reducing } \\
\text { sugar \% }\end{array}$ & $\begin{array}{c}\text { Non-reducing } \\
\text { sugar } \%\end{array}$ \\
\hline 45 & $31.05^{\star} \pm 0.02$ & $2.28^{\star} \pm 0.015$ & $28.77^{\star} \pm 0.006$ \\
\hline 128 & $28.09^{\star} \pm 0.02$ & $0.825^{\star} \pm 0.002$ & $27.27^{\star} \pm 0.015$ \\
\hline 293 & $23.62^{\star} \pm 0.02$ & $0.908 \pm 0.002$ & $22.71^{\star} \pm 0.02$ \\
\hline 412 (control) & $25.26 \pm 0.02$ & $0.905 \pm 0.002$ & $24.36 \pm 0.015$ \\
\hline 622 & $26.68^{\star} \pm 0.025$ & $1.42^{*} \pm 0.02$ & $25.26^{\star} \pm 0.045$ \\
\hline
\end{tabular}

Data are means of triplicate \pm SD. *The mean difference is significant at $P \leq 0.05$

Table 1: Effect of Nitrogen concentrations on total carbohydrates, reducing and non-reducing sugars contents of Spirulina platensis cells.

\begin{tabular}{|c|c|c|c|c|}
\hline \multirow{2}{*}{ Treatments } & \multicolumn{2}{|c|}{$\begin{array}{c}\text { Hot Water extracts } \\
\text { Total }\end{array}$} & \multicolumn{2}{|c|}{$\begin{array}{c}\text { Ethanol extracts } \\
\text { Total }\end{array}$} \\
\hline & carbohydrate $\%$ & Sulfate $\%$ & carbohydrate $\%$ & Sulfate $\%$ \\
\hline $\begin{array}{l}\text { S.platensis grown } \\
\text { at } 45 \mathrm{ppm} \mathrm{N}\end{array}$ & $\begin{array}{c}7.60^{*} \\
\pm 0.200\end{array}$ & $\begin{array}{c}2.35^{\star} \\
\pm 0.020\end{array}$ & $\begin{array}{c}8.06^{*} \\
\pm 0.122\end{array}$ & $\begin{array}{c}5.02^{*} \\
\pm 0.015\end{array}$ \\
\hline $\begin{array}{l}\text { S.platensis grown } \\
\text { at } 128 \mathrm{ppm} \mathrm{N}\end{array}$ & $\begin{array}{c}8.60^{*} \\
\pm 0.200\end{array}$ & $\begin{array}{c}3.13^{*} \\
\pm 0.120\end{array}$ & $\begin{array}{c}9.30^{*} \\
\pm 0.200\end{array}$ & $\begin{array}{l}5.40^{*} \\
\pm 0.200\end{array}$ \\
\hline $\begin{array}{l}\text { S.platensis grown } \\
\text { at } 293 \mathrm{ppm} \mathrm{N}\end{array}$ & $\begin{array}{c}10.30^{*} \\
\pm 0.200\end{array}$ & $\begin{array}{l}3.26^{*} \\
\pm 0.020\end{array}$ & $\begin{array}{l}10.80^{*} \\
\pm 0.300\end{array}$ & $\begin{array}{c}2.13^{*} \\
\pm 0.162\end{array}$ \\
\hline $\begin{array}{l}\text { S.platensis grown } \\
\text { at } 412 \mathrm{ppm} \mathrm{N}\end{array}$ & $\begin{array}{c}17.83 \\
\pm 0.252\end{array}$ & 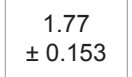 & $\begin{array}{c}12.77 \\
\pm 0.153\end{array}$ & $\begin{aligned} & 4.13 \\
\pm & 0.153\end{aligned}$ \\
\hline $\begin{array}{l}\text { S.platensis grown } \\
\text { at } 622 \mathrm{ppm} \mathrm{N}\end{array}$ & $\begin{array}{l}9.40^{*} \\
\pm 0.200\end{array}$ & $\begin{array}{c}0.94^{*} \\
\pm 0.064\end{array}$ & $\begin{array}{l}13.16^{*} \\
\pm 0.216\end{array}$ & $\begin{array}{c}4.05 \\
\pm 0.02\end{array}$ \\
\hline
\end{tabular}

Data are means of triplicate $\pm S D$. *The mean difference is significant at $\mathrm{P} \leq 0.05$

Table 2: Effect of extraction methods of sulfated polysaccharides of S.platensis grown under different nitrogen concentrations on total carbohydrates. 
Citation: Abd El Baky H, Hanaa El Baz KF, EL-Latife SA (2013) Induction of Sulfated Polysaccharides in Spirulina platensis as Response to Nitrogen Concentration and its Biological Evaluation. J Aquac Res Development 5: 206 doi:10.4172/2155-9546.1000206

Page 4 of 8

concentration of sulfate (3.26\%). However, in sulfated polysaccharide extracted with ethanol from S. Platensis grown on media containing $128 \mathrm{ppm}$ nitrogen gave the highest concentrations of sulfate $5.4 \%$. These results indicated that extraction with ethanol $85 \%$ gave the highest concentration of total carbohydrates and sulfate content.

\section{Monosaccharides profile of $S$. platensis sulfated polysaccharides}

The sulfated polysaccharides hydrolysates of S. Platensis grown at different concentration of nitrogen were analyzed by HPLC. The results showed that glucouronic acids (ranged from $2.075-45.15 \mathrm{mg} / \mathrm{g}$ ) was found to be predominant constituents in all extracts (Table 3), followed by Galactose $(0.57-2.495 \mathrm{mg} / \mathrm{g})$ and then glucose $(1.88-131.125 \mathrm{mg} / \mathrm{g})$. While, rhamnose and arabinose was present as a minor constituents. However, the sulfated polysaccharide extracted with hot water from S. Platensis grown on media containing $128 \mathrm{ppm}$ nitrogen had a highest value of glucouronic acid, and had new sugar appeared its ribose as combined with other treatments. It has been shown by previous workers that, the initial analyses indicated that calcium spirulan (Ca-SP) was composed of rhamnose, ribose, mannose, fructose, galactose, xylose, glucose, glucuronic acid, and galacturonic acid [31].

\section{Infrared spectra of $S$. platensis sulfated polysaccharides}

IR spectrum was recorded for all SPS extracted from S. Platensis (Figure 2). All the S. Platensis extracts showed similar IR spectra. They had a several peaks corresponding to sulfate ester: the intense band at $790-850 \mathrm{~cm}^{-1}$ derived from the bending vibration of $\mathrm{C}-\mathrm{O}-\mathrm{S}$ of sulfate in axial position and stretching vibration of $\mathrm{S}-\mathrm{O}$ of sulfate, respectively [32]. In addition, a strong band at $740-880 \mathrm{~cm}^{-1}$ was due to asymmetric stretch vibration of COO- of uronic acids; $1440-1460 \mathrm{~cm}^{-1}$, symmetric stretch vibration of $\mathrm{COO}$ - and stretch vibration of $\mathrm{C}-\mathrm{O}$ within $\mathrm{COOH}$. The large absorption band centered on $3400-4450 \mathrm{~cm}^{-1}$, which caused by a large amount of $\mathrm{O}-\mathrm{H}$ stretching. These results are in agreement with that found by Yang et al. [33], Mao et al. [32] and Abd El Baky et al. [34] which describing a symmetrical C-O-S vibration associated to a C-O-SO group at $819 \mathrm{~cm}^{-1}$ and a discernible shoulder at $857 \mathrm{~cm}^{-1}$ was also due to the symmetrical C-O-S vibration.

\section{Biological evaluation of S. Platensis sulfated polysaccharides}

Antimicrobial activity of $S$. Platensis sulfated polysaccharides: Sulfated polysaccharide extracted with hot water from S. Platensis grown on medium containing $128 \mathrm{ppm}$ nitrogen recorded significant antimicrobial activity on yeast $(8 \mathrm{~mm})$ and fungi $(10 \mathrm{~mm})$, however there was no activity recorded on Gram-negative and Gram-positive

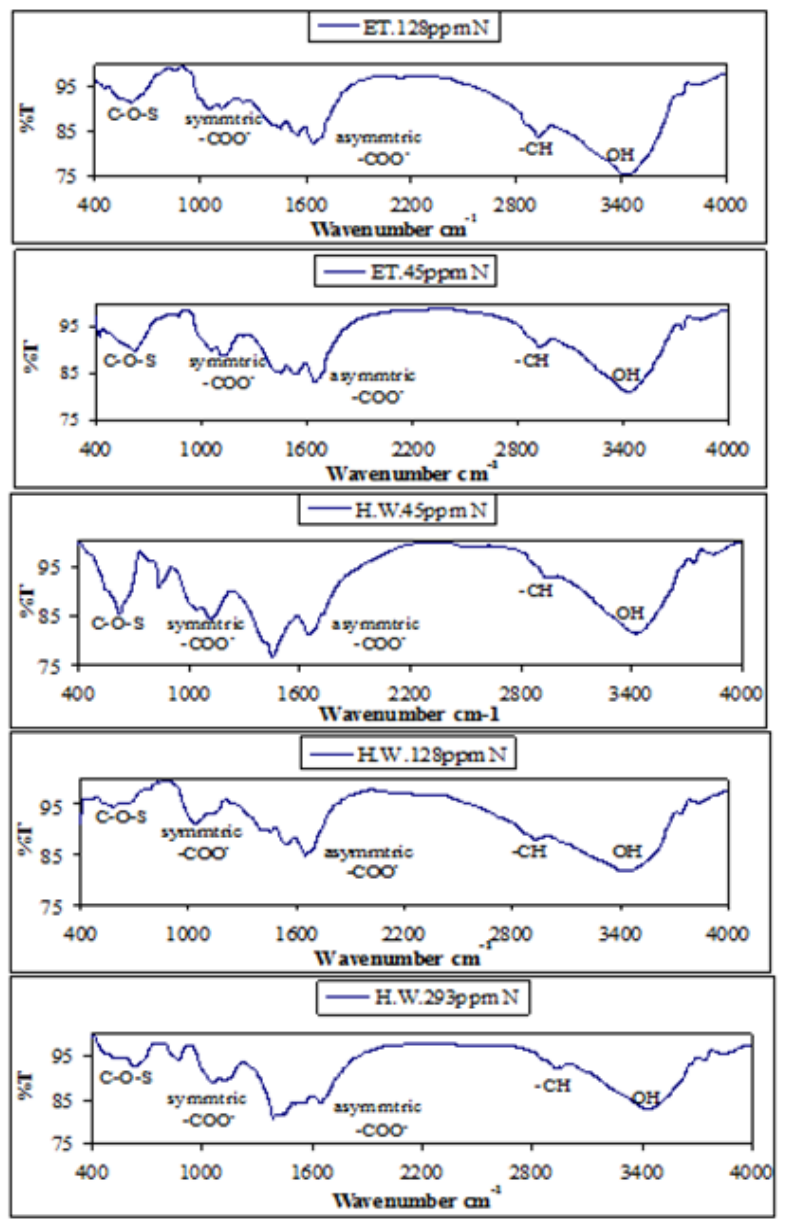

Figure 2: Infrared Spectra of Sulfated polysaccharide extracts. ET-Ethano extract \& H.W-Hot water extract.

\begin{tabular}{|c|c|c|c|c|c|c|c|c|c|c|c|c|}
\hline \multirow[t]{2}{*}{ EXTRACTS } & \multicolumn{12}{|c|}{ Mono sugars content (mg/g) } \\
\hline & $\begin{array}{l}\text { Glucuronic } \\
\text { acid(mg/g) }\end{array}$ & $\begin{array}{l}\text { Molar } \\
\text { Ratio }\end{array}$ & $\begin{array}{c}\text { Galactose } \\
(\mathrm{mg} / \mathrm{g})\end{array}$ & $\begin{array}{l}\text { Molar } \\
\text { Ratio }\end{array}$ & $\begin{array}{c}\text { Glucose } \\
(\mathrm{mg} / \mathrm{g})\end{array}$ & $\begin{array}{r}\text { Molar } \\
\text { Ratio }\end{array}$ & $\begin{array}{c}\text { Rhamnose } \\
(\mathrm{mg} / \mathrm{g})\end{array}$ & $\begin{array}{l}\text { Molar } \\
\text { Ratio }\end{array}$ & $\begin{array}{c}\text { Arabinose } \\
(\mathrm{mg} / \mathrm{g})\end{array}$ & $\begin{array}{l}\text { Molar } \\
\text { Ratio }\end{array}$ & $\begin{array}{l}\text { Ribose } \\
(\mathrm{mg} / \mathrm{g})\end{array}$ & $\begin{array}{l}\text { Molar } \\
\text { Ratio }\end{array}$ \\
\hline $\begin{array}{l}\text { SPS Extracted with hot water } \\
\text { fromSpirulina grown on medium } \\
\text { containing } 45 \mathrm{ppm} \mathrm{N}\end{array}$ & 18.33 & 114.56 & - & & 0.16 & 1 & 1.005 & 6.28 & 24.2 & 151.25 & - & \\
\hline $\begin{array}{l}\text { SPS Extracted with hot water } \\
\text { fromSpirulina grown on medium } \\
\text { containing } 128 \text { ppm N }\end{array}$ & 45.15 & 1 & - & & - & & - & & - & & 387.22 & 8.576 \\
\hline $\begin{array}{l}\text { SPS Extracted with hot water } \\
\text { fromSpirulina grown on medium } \\
\text { containing } 293 \text { ppm N }\end{array}$ & 3.28 & 41 & 2.495 & 31.18 & 0.08 & 1 & - & & - & & - & \\
\hline $\begin{array}{l}\text { SPS Extracted with Ethanol } \\
\text { from Spirulina grown on medium } \\
\text { containing } 45 \mathrm{ppm} \mathrm{N}\end{array}$ & 2.455 & 44.63 & 0.57 & 10.36 & 0.055 & 1 & - & & 1.08 & 19.63 & - & \\
\hline $\begin{array}{l}\text { SPS Extracted with Ethanol } \\
\text { from Spirulina grown on medium } \\
\text { containing } 128 \mathrm{ppm} \mathrm{N}\end{array}$ & 2.075 & 24.41 & 0.575 & 6.76 & 0.085 & 1 & 0.635 & & & - & & - \\
\hline
\end{tabular}

Molar ratio calculated as: By comparing the retention time of the standard peaks and the sample peak, the composition of the extracts

Table 3: HPLC Profile of S.platensis sulphated Polysaccharides. 
Citation: Abd El Baky H, Hanaa El Baz KF, EL-Latife SA (2013) Induction of Sulfated Polysaccharides in Spirulina platensis as Response to Nitrogen Concentration and its Biological Evaluation. J Aquac Res Development 5: 206 doi:10.4172/2155-9546.1000206

Page 5 of 8

bacterial species (Table 4). Anderson et al. [35] studied the interaction of heparan sulfate and other glycosaminoglycans (GAGs) with their respective receptors may also be involved in tissue penetration by spermatozoa and infectious microbes. GAGs have a key role in viral and bacterial infectivity, phagocytosis and endocytosis, intercellular communication, and cell-cell interaction. According to Mendiola et al. [36] four different microbial species, including a gram negative bacterium (Escherichia coli), a gram positive bacterium (Staphylococcus aureus), a yeast (Candida albicans) and a fungus (Aspergillus niger), were used to screen the possible antimicrobial activity of Spirulina platensis supercritical fluid extracts. The antimicrobial activity was quantitatively assessed by the determination of the minimum inhibitory concentration (MIC) and minimal bactericidal and fungicidal concentration (MBC). Results obtained showed that $C$. albicans was the most sensitive microorganism to all Spirulina fractions, with the lowest $\mathrm{MBC}$ values $(15-10 \mathrm{mg} / \mathrm{ml})$, whereas the least susceptible was the fungus $A$. niger. Sulfated polysaccharides serve a number of structural and protective roles in algal cell and plants. The extensive range of their physiological functions has only recently begun to be appreciated and explored [37].

Antiviral activity of S. Platensis sulfated polysaccharides: As shown in Table 5 the extracts were evaluated for their antiviral activity against HSV-1 (standard strain) as a model of DNA virus by a plaque reduction assay. The sulfated polysacch-aride extracted with hot water from S. Platensis grown on medium containing $45 \mathrm{ppm}$ nitrogen showed the highest antiviral activity when the concentration of $20 \mu \mathrm{g}$ was applied. An explanation of these results may be due to that this extract has a high molecular weight sulfated polysaccharides than the two other extracts. In general, the antiviral activities of sulfated polysaccharides increased with the degree of sulfation and molecular weight. This result is in agreement with that found by Asker et al. [12]. It is of interest to note that the influence of the distribution of sulfate groups along polymer chain and the conformational flexibility of this chain for adopting a definite shape which might be required during the formation of polysaccharide-virus complex. On the other hand, Chirasuwan et al. [38] studied the role of sulfate groups in the polysaccharides extracted from S. Platensis by eliminated sulfate groups

\begin{tabular}{|c|c|c|c|c|}
\hline \multirow[t]{2}{*}{ Extracts } & \multicolumn{4}{|c|}{ Microorganism (Diameter of inhibition zone $(\mathrm{mm})$} \\
\hline & $\begin{array}{c}\text { Bacillus subtiles } \\
(\mathrm{Gr}+\mathrm{ve} \\
\text { bacteria) }\end{array}$ & $\begin{array}{c}\text { Escherichia } \\
\text { coli }(\mathrm{Gr}-\mathrm{ve} \\
\text { bacteria) }\end{array}$ & $\begin{array}{c}\text { Candida } \\
\text { albicans } \\
\text { (yeast) }\end{array}$ & $\begin{array}{c}\text { Aspergillus } \\
\text { niger } \\
\text { (fungi) }\end{array}$ \\
\hline $\begin{array}{l}\text { SPS extracted with hot } \\
\text { water from Spirulina grown } \\
\text { on medium containing } 45 \\
\text { ppm nitrogen }\end{array}$ & -- & -- & -- & -- \\
\hline $\begin{array}{l}\text { SPS extracted with hot } \\
\text { water from Spirulina grown } \\
\text { on medium containing } 128 \\
\text { ppm nitrogen }\end{array}$ & -- & -- & -- & -- \\
\hline $\begin{array}{l}\text { SPS extracted with hot } \\
\text { water from Spirulina grown } \\
\text { on medium containing } 293 \\
\text { ppm nitrogen }\end{array}$ & -- & -- & -- & -- \\
\hline $\begin{array}{l}\text { SPS extracted with ethanol } \\
\text { from Spirulina grown on } \\
\text { medium containing } 45 \mathrm{ppm} \\
\text { nitrogen }\end{array}$ & -- & -- & -- & -- \\
\hline $\begin{array}{l}\text { SPS extracted with ethanol } \\
\text { from Spirulina grown on } \\
\text { medium containing } 128 \\
\text { ppm nitrogen }\end{array}$ & -- & -- & 8 & 10 \\
\hline
\end{tabular}

Table 4: Antimicrobial activity of sulfated polysaccharaides of Spirulina grown under different nitrogen concentrations. before testing for anti HSV-1, the results indicated that in the absence of sulfate groups in polysaccharide, no significant anti HSV-1 activity was detected.

Anticoagulant activity of $S$. Platensis sulfated polysaccharides: Data concerning the anticoagulating activity of sulfated polysaccharide extracted with hot water and ethanol from Spirulina platensis are shown in Table 6. Heparin was used as standard anticoagulant. Generally, the anticoagulant activities of the extracts were less than heparin. The same results were obtained in sulfated polysaccharides extracted with hot water and ethanol from S. Platensis under different nitrogen concentrations. The effect of extracts, which possess anticoagulating activity, may be due to the presence of uronic acids. The polysaccharides containing uronic acids, carrying negative charge, have the ability for binding calcium ions and therefore prevent the formation of clot. In addition, variation in anticoagulating activity of the different extracts is probably due to the quantity of uronic acids in polysaccharides and some conformational differences in the molecules of these polysaccharides [34-39]. While, Mao et al. [32] mentioned that the anticoagulant activities of the sulfated polysaccharides from the green algae Ulva conglobata were weaker than heparin on the same concentration In order to study the inhibitory mechanism of the sulfated polysaccharides, the effect on thrombin activity was investigated using chromogenic substrate in the presence and in the absence of antithrombin or heparin cofactor II. In general, heparin cofactor II is a serine protease inhibitor and selectively inhibits thrombin, and antithrombin inhibits all intrinic pathway coagulation enzymes. These results suggest that the anticoagulant properties of the sulfated polysaccharides are attributed to the direct inhibition and heparin cofactor II media-ted inhibition of thrombin activity. Anti-coagulant activity is largely dependent on the sugar

\begin{tabular}{|c|c|c|}
\hline \multirow{2}{*}{ Samples } & \multicolumn{2}{|c|}{$\begin{array}{c}\text { \%Anticoagulant activity* } \\
\text { Time of clotting }\end{array}$} \\
\cline { 2 - 3 } & Hot water & Ethanol \\
\cline { 2 - 3 } & extract & extract \\
\hline Blank & -- & -- \\
Heparint & $100 \%$ & $100 \%$ \\
S.platensis grown at 45 ppm N & $80 \%$ & $60 \%$ \\
S.platensis grown at 128 ppm N & $80 \%$ & $60 \%$ \\
S.platensis grown at 293 ppm N & $80 \%$ & $60 \%$ \\
S.platensis grown at 412 ppm N & $80 \%$ & $60 \%$ \\
S.platensis grown at 622 ppm N & $80 \%$ & $60 \%$ \\
\hline
\end{tabular}

* Relative Percentage

Table 5: Anticoagulant activities of sulfated polysaccharide extracts of Spirulina platensis.

\begin{tabular}{|l|c|c|c|}
\hline Extracts & $\begin{array}{c}\text { Conc. } \\
(\boldsymbol{\mu g})\end{array}$ & $\begin{array}{c}\text { \% Viral } \\
\text { Inhibition }\end{array}$ & IC $_{50}$ \\
\hline SPS extracted with hot water from Spirulina & $10 \mu \mathrm{g}$ & 28.12 & 17.78 \\
\hline grown on medium containing 45 ppm nitrogen & $20 \mu \mathrm{g}$ & 28.12 & \\
\hline SPS extracted with hot water from Spirulina & $10 \mu \mathrm{g}$ & 9.37 & 53.36 \\
\hline grown on medium containing 128 ppm nitrogen & $20 \mu \mathrm{g}$ & 12.5 & \\
\hline SPS extracted with hot water from Spirulina & $10 \mu \mathrm{g}$ & 9.37 & 53.36 \\
\hline grown on medium containing 293 ppm nitrogen & $20 \mu \mathrm{g}$ & 25 & \\
\hline SPS extracted with ethanol from Spirulina & $10 \mu \mathrm{g}$ & 25 & 20 \\
\hline grown on medium containing 45 ppm nitrogen & $20 \mu \mathrm{g}$ & 34.37 & \\
\hline SPS extracted with ethanol from Spirulina & $10 \mu \mathrm{g}$ & 12.5 & 40 \\
\hline grown on medium containing 128 ppm nitrogen & $20 \mu \mathrm{g}$ & 15.6 & \\
\hline
\end{tabular}

Table 6: In-Vitro antiviral activity of sulfated polysaccharides extracts assessed on HSV1. 
Citation: Abd El Baky H, Hanaa El Baz KF, EL-Latife SA (2013) Induction of Sulfated Polysaccharides in Spirulina platensis as Response to Nitrogen Concentration and its Biological Evaluation. J Aquac Res Development 5: 206 doi:10.4172/2155-9546.1000206

Page 6 of 8

composition, sulfate content, sulfate position and molecular weight of the compound. The correlation also suggests that suitable length and/or conformation and moderate extent of negative charge density of the polysaccharide molecule would be required for express-ion of its effective anticoagulant activity [40]. It has been shown that Ca-SP activates heparin cofactor II, a physiological inhibitor of thrombin, and exhibits antithrombin activity in vitro by a unique mechanism different from that of heparin [41].

\section{Antioxidant activity of $S$. Platensis sulfated polysaccharides:}

DPPH radical scavenging: DPPH. is used as a free radical to evaluate antioxidant activity of S. Platensis extracts. The degree of its discoloration might attribute to hydrogen donating ability of test extracts [42]. Table 7 showed \% scavenging of extracts with different concentrations of all extracts, BHA and BHT Significant DPPH radical scavenging activity was evident in hot water extract of S. Platensis grown on medium containing $128 \mathrm{ppm}$ nitrogen at concentration 300 $\mu \mathrm{g}$. However, all extracts showed lower activities than BHA and BHT at the same concentration. Zhao et al. [43] mentioned that low molecular weight sulfated polysaccharide has the potential ability to stop free radical reactions from the start and to inhibit the damage induced by excess free radical. However, the relationship between the structure of algal polysaccharides and antioxidative mechanisms has not yet been elucidated [24].

ABTS $^{++}$radical scavenging activity: Table 8 showed \% scavenging of extracts with different concentrations, and standard antioxidant Trolox. Significant $\mathrm{ABTS}^{+}$radical scavenging activity was evident in hot water extract of S. Platensis grown in medium containing $293 \mathrm{ppm}$ nitrogen at concentration $400 \mu \mathrm{g}$. However, all extracts showed lower activities than Trolox. Other results noted that there is a positive correlation between sulfate content and antioxidant activity [44]. There findings lend weight to the content of sulfated polysaccharides in different S. Platensis extracts, which might explain their high antioxidant activities, that a direct correlations between sulfated polysaccharides content of algal and its antioxidant activity is observed. Hence, the all tested sample with scavenging activity had the same structure feature in that all of them

\begin{tabular}{|l|c|c|c|}
\hline \multirow{2}{*}{ Extracts } & \multicolumn{3}{|c|}{ Scavenging\% } \\
\cline { 2 - 4 } & \multicolumn{3}{|c|}{ Concentration $(\boldsymbol{\mu g})$} \\
\hline SPS extracted with hot water from Spirulina & $30.55^{* *}$ & $32.05^{* *}$ & $35.36^{* *}$ \\
\hline grown on medium containing 45 ppm nitrogen & \pm 0.020 & \pm 0.025 & \pm 0.03 \\
\hline SPS extracted with hot water from Spirulina & $39.73^{* * *}$ & $40.67^{* *}$ & $68.29^{* *}$ \\
\hline grown on medium containing 128 ppm nitrogen & \pm 0.026 & \pm 0.02 & \pm 0.02 \\
\hline SPS extracted with hot water from Spirulina & $28.23^{* *}$ & $35.69^{* *}$ & $44.66^{* *}$ \\
\hline grown on medium containing 293 ppm nitrogen & \pm 0.020 & \pm 0.025 & \pm 0.02 \\
\hline SPS extracted with ethanol from Spirulina & $26.37^{* * *}$ & $28.05^{* *}$ & $30.05^{\star * *}$ \\
\hline grown on medium containing 45 ppm nitrogen & \pm 0.020 & \pm 0.02 & \pm 0.006 \\
\hline SPS extracted with ethanol from Spirulina & $25.75^{* * *}$ & $26.63^{* *}$ & $30.16^{* *}$ \\
\hline grown on medium containing 128 ppm nitrogen & \pm 0.020 & \pm 0.025 & \pm 0.025 \\
\hline BHA & 88.54 & 95.22 & 99.41 \\
\hline & \pm 0.020 & \pm 0.02 & \pm 0.025 \\
\hline BHT & $85.57^{*}$ & $94.76^{*}$ & $98.15^{*}$ \\
\hline & \pm 0.025 & \pm 0.031 & \pm 0.046 \\
\hline
\end{tabular}

Data are means of triplicate \pm SD

$\left.{ }^{*}\right)$ The mean difference is significant at $\mathrm{P} \leq 0.05$ relative to $\mathrm{BHA}$

$\left({ }^{*}\right)$ The mean difference is significant at $\mathrm{P} \leq 0.05$ relative to $\mathrm{BHT}$

Table 7: Antioxidant activity of sulfated polysaccharides extracts assessed by DPPH. had many $-\mathrm{OH}$ and $-\mathrm{OSO}_{3} \mathrm{H}$ groups in the molecules. Their groups had a significant effect on scavenging free radicals. Polysaccharides promote antioxidant activity, which exhibited the greater of abstraction of anomaric hydrogen from the internal monosaccharide units [34,45]. Also, polysaccharide like alginic acid can absorption of toxic chemicals and free radical [46]. Therefore, S. Platensis exert antioxidant action by breaking the free radical chain by donating a hydrogen atom [47].

Cytotoxic activity of $S$. Platensis sulfated polysaccharides: The cytotoxic tests (Table 9) revealed that, sulfated polysaccharide extracted with hot water from S. Platensis showed a significant inhibition \% against HepG2 and MCF7 (86.99, 88.51 \%, respectively) While IC $_{50}$ for sulfated polysaccharide extracted with hot water was $0.54 \mu \mathrm{g}$ from $S$. Platensis grown on media containing 293 ppm nitrogen against HepG2. It was $0.40 \mu \mathrm{g}$ for sulfated polysaccharide extracted with hot water from S. Platensis grown on media containing $293 \mathrm{ppm}$ nitrogen against MCF7.

These results may be apparently related to their chemical constituents present in their algal polysaccharides, in particular, for sulfate contents in S. Platensis polysaccharide. The ability of algal polysaccharides to inhibit the proliferation of many cultured of cancer cells has been well documented [34,45]. Moreover, a marine algae

\begin{tabular}{|l|c|c|c|c|}
\hline \multirow{2}{*}{ Extracts } & \multicolumn{4}{|c|}{ Scavenging\% } \\
\cline { 2 - 5 } & \multicolumn{3}{|c|}{ Concentration( $\mu$ g) } \\
\hline SPS extracted with hot water from Spirulina & $40.04^{*}$ & $45.44^{*}$ & $46.37^{*}$ & $49.03^{*}$ \\
\hline grown on medium containing 45 ppm nitrogen & \pm 0.025 & \pm 0.035 & \pm 0.025 & \pm 0.076 \\
\hline SPS extracted with hot water from Spirulina & $39.41^{*}$ & 44.84 & $49.96^{*}$ & $51.81^{*}$ \\
\hline grown on medium containing 128 ppm nitrogen & \pm 0.025 & \pm 0.020 & \pm 0.015 & \pm 0.020 \\
\hline SPS extracted with hot water from Spirulina & $51.91^{*}$ & $57.74^{*}$ & $59.57^{*}$ & $71.12^{*}$ \\
\hline grown on medium containing 293 ppm nitrogen & \pm 0.021 & \pm 0.035 & \pm 0.025 & \pm 0.020 \\
\hline SPS extracted with ethanol from Spirulina & $34.17^{*}$ & $41.11^{*}$ & $46.69^{*}$ & $64.48^{*}$ \\
\hline grown on medium containing 45 ppm nitrogen & \pm 0.020 & \pm 0.076 & \pm 0.776 & \pm 0.020 \\
\hline SPS extracted with ethanol from Spirulina & $34.47^{*}$ & $38.77^{*}$ & $42.23^{*}$ & 56.09 \\
\hline grown on medium containing 128 ppm nitrogen & \pm 0.020 & \pm 0.153 & \pm 0.025 & \pm 0.012 \\
\hline Trolox & 92.35 & 95.66 & 98.23 & 99.45 \\
\hline & \pm 0.020 & \pm 0.020 & \pm 0.038 & \pm 0.131 \\
\hline
\end{tabular}

Data are means of triplicate $\pm S D$. * The mean difference is significant at $P \leq 0.05$ Table 8: Antioxidant activity of sulfated polysaccharides extracts assessed by ABTS $^{+}$

\begin{tabular}{|c|c|c|c|c|}
\hline \multirow{3}{*}{ Extracts $(10 \mu \mathrm{g})$} & \multirow{2}{*}{\multicolumn{3}{|c|}{$\begin{array}{c}\mathrm{IC}_{50}(\mu \mathrm{g}) \\
\% \text { Inhibition }\end{array}$}} & \multirow[b]{3}{*}{ MCF7 } \\
\hline & & & & \\
\hline & HepG2 & MCF7 & HepG2 & \\
\hline SPS extracted with hot water from Spirulina & 80.59 & 81.85 & 3.09 & 0.74 \\
\hline \multicolumn{5}{|l|}{ grown on medium containing 45 ppm nitrogen } \\
\hline SPS extracted with hot water from Spirulina & 78.56 & 88.8 & 3.69 & 0.47 \\
\hline \multicolumn{5}{|l|}{ grown on medium containing 128 ppm nitrogen } \\
\hline SPS extracted with hot water from Spirulina & 83.67 & 88.09 & 0.54 & 0.4 \\
\hline \multicolumn{5}{|l|}{ grown on medium containing 293 ppm nitrogen } \\
\hline SPS extracted with ethanol from Spirulina & 85.1 & 88.51 & 1.68 & 0.74 \\
\hline \multicolumn{5}{|l|}{ grown on medium containing 45 ppm nitrogen } \\
\hline SPS extracted with ethanol from Spirulina & 86.99 & 82.88 & 2.82 & 0.47 \\
\hline \multicolumn{5}{|l|}{ grown on medium containing $128 \mathrm{ppm}$ nitrogen } \\
\hline Novatron ( standard) & 59.5 & 52.81 & 4 & 1.4 \\
\hline
\end{tabular}

Table 9: Cytotoxic activity of sulfated polysaccharides extracts assessed on HepG2 and MCF7 cell lines. 
Citation: Abd El Baky H, Hanaa El Baz KF, EL-Latife SA (2013) Induction of Sulfated Polysaccharides in Spirulina platensis as Response to Nitrogen Concentration and its Biological Evaluation. J Aquac Res Development 5: 206 doi:10.4172/2155-9546.1000206

contains large amounts of characterized polysaccharides such as fucoidan, carrageenan and calcium spirulan etc. exhibited anti-tumor, anti-cancer and-anti-metastatic properties and they also reduce cell proliferation [48]. However, their activity may be correlated with the presence of sulfate and uronic groups in their compounds [45,49,50].

In the present work the effect of sodium nitrate concentration on the production of biomass was studied and the maximum growth was achieved in control medium (412 ppm nitrogen). However, cultivation of S. Platensis on media containing 412, $293 \mathrm{ppm}$ nitrogen gave the highest values of sulfate and S. Platensis grown on media containing 45 and $128 \mathrm{ppm}$ nitrogen gave the highest values of total carbohydrate, reducing and non-reducing sugars. In addition, the results showed that all extracts have anticoagulant activity but not as high as heparin. On the other hand, it acts as anticancer agent against liver carcinoma cell line (HepG2) and breast carcinoma cell line (MCF7), and has antimicrobial and antiviral activities. Further investigations on sulfated polysaccharides are needed to explore its mode of action and its related chemical composition and applications.

Polysaccharide can absorption of toxic chemical substances and it plays a major role as dietary fiber for the maintenance of animal and human health [41]. These dietary polysaccharides are not found in any land plants. They help protect against potential carcinogens $S$. Platensis grown on media containing 45 and $128 \mathrm{ppm}$ nitrogen gave the highest values of sulfated polysaccharides and has a higher amount of sulfate ester groups and high molecular weight than the other fraction. In general, the bioactivity (as antiviral, anticancer and antimicrobial activity) of sulfated polysaccharides increases with the degree of salvation and molecular weight [51]. A next point of interest is the influence of the distribution of sulfate groups along polymer chain and the conformational flexibility of this chain for adopting a definite shape that might be required during the formation of polysaccharide-virus complex [52]. It is likely that post-infection involved inhibition of early post absorption steps such as virus internalization and inhibition of cell-to-cell transmission in successive cycles of replication.

\section{Conclusion}

Spirulina platensis accumulate a high amount of sulfated polysaccharides it had biological activities as anticoagulant, anticancer, antiviral, antimicrobial, and antioxidant.

\section{Acknowledgements}

The work was supported by National Research Centre, Egypt, grants.

\section{References}

1. Abd El BH Hanaa, El Baz FK, El-Baroty GS (2003) Spirulina Species as a Source of Carotenoids and A-Tocopherol and Its Anticarcinoma Factors. Biotechol 2: 222-240.

2. Colla LM, Reinehr CO, Reichert C, Costa JAV(2007) Production of Biomass and Nutraceutical Compounds By ¡Spirulina platensis Under Different Temperature and Nitrogen Regimes. Bioresource Technol 98: 1489-1493;.

3. Nie X, Shi B, Ding Y, Tao W (2006) Preparation of a Chemically Sulfated Polysaccharide Derived From Grifola Frondosa and Its Potential Biological Activities. Inter J Biologi Macromolecules 39: 228-233.

4. Chaidedgumjorn A, Toyoda H, Woo ER, Lee KB, Kim YS et al. (2002) Effect of $(1 \rightarrow 3)$ - and $(1 \rightarrow 4)$-Linkages of Fully Sulfated Polysaccharides on their Anticoagulant Activity. Carbohydrate Res 337: 925-933.

5. Wu Q, Zhang C, Ning Z (2006) Study on Extracting Tremella Fuciformis Polysaccharides With Microwave- Assisted Extraction. Food Sci Technol 9: 109-111.

6. Kaji T, Okabea M, Shimadaa S, Yamamotoa C, Fujiwaraa Y et al. (2004) Sodium Spirulan as a Potent Inhibitor of Arterial Smooth Muscle Cell Proliferation Invitro. Life Sci 74: 2431-2439.
7. Hayakawa Y, Hayashi T, Hayashi K, Ozawa T, Niiya K et al. (1997) Calcium Spirulan as an Inducer of Tissue-Type Plasminogen Activator in Human Fetal Lung Fibroblasts. Biochimica et Biophysica Acta, 1355: 241-247.

8. Zarrouk C (1966) Contribution Á L'étude Ďune Cyanophycée: Influence De Divers Facteurs Physiques Et Chimiques Sular Croissance Et La Photosynthése De Spirulina Maxima (Setch Et Gardner) Geitler.

9. Raoof B, BD Kaushik, R Prasanna (2006) Formulation of a Low-Cost Medium for Mass Production of Spirulina. Biomass and Bioenergy 30: 537-542.

10. Reichert CC, CO Reinehr, JAV Costa (2006) Semi Continuous Cultivation of the Cyan Bacterium Spirulina platensis in a Closed Photoreactor. Brazilian J Chem Engineering 23: 23-28.

11. Payer HD (1971) First Report Upon The Organization and Experimental Work of The Thailand German Project on the Production and Utilization of Single Cel Green Algae as Protein Source for Human Nutrition. Inst. of Food Res. and Product Development Kasetsar Univ., Bangkok, Thailand.

12. Asker MSM, SF Mohamed, FM Ali, OH El-Sayed (2007) Chemical Structure and Antiviral Activity of Water-Soluble Sulfated Polysaccharides From Surgassum Latifolium. J Appl Sc Res 3: 1178-1185.

13. Berovic M, J Habijanic, I Zore, B Waber, D Hodzer et al. (2003) Submerged Cultivation of Ganoderma Lucidum Biomass and Immunostimulatory Effects of Fungal Polysaccharides. J Biotech 103: 77-86.

14. Pugh N, Ross SA, El-Sohly HN, El-Sohly MA, Pasco DS (2001) Isolation of Three High Molecular Weight Polysaccharide Preparations with Potent Immunostimulatory Activity From Spirulina platensis, Aphanizomenon FlosAquae and Chlorella Pyrenoidosa. Planta Med 67: 737-742.

15. Yim JH, Kim SJ, Ahn SH, Lee CK, Rhie KT et al. (2004) Antiviral Effects of Sulfated Exopolys-Accharide From The Marine Microalgae Gyrodinium Impudiucum Strain KGO3. Marine Biotechnol 6: 17-25

16. Dubois M, Gilles KA, Hamilton JK, Rebers PA, Smith F (1956) Colourimeteric Method For Determination of Sugars and Related Substances. Anal Chem 28: 350-356.

17. Miller GL (1959) Use of Dinitrosalicylic Acid Reagent For Determination of Reducing Sugars. Anal. Chem 31: 426-428.

18. Terho TT, K Hartiala (1971) Method for Determination of the Sulfate Content of Glycosaminoglycans. Anal Biochem 41: 471-476.

19. El-Sayed OH, SA Ismail, YM Ahmed, M Abd El-Samei, MMS Asker (2005) Studies On The Production Of Sulfated Polysaccharide By Locally Isolated Bacteria. Egyp Pharmaceutical J 4: 439-452.

20. RK Finn (1959) Theory of Agar Diffusion Method for Bioassay. Anal Chem 31 : 975-977.

21. Gabraith H, Miller T, Paton A, Thompson J (1971) Antibacterial Activity of Long Chain Fatty Acids and the Reversal with Calcium, Magnesium, Ergocalcferole and Cholesterol. J Appl Bact 4: 803-813.

22. Silva OS, Barbose A, Diniz M, Valdeira, Gomes E (1997) Plant Extracts Antivira Activity Against Herps Simplex Virus Type 1 and Africane Swine Fever Virus. Inter J Pharm 35: 12-16.

23. USA Pharmacopeia, (1985). Pharma-Copeia of United State of America. Mack Puplishing Combing. 482 Cited By : El-Baroty Et Al. (2005)

24. Ye H, Wang K, Zhou C, Liu J, Zeng X (2008) Purification, Antitumor and Antioxidant Activities in Vitro of Polysaccharides from The Brown Seaweed Sargassum Pallidum. Food Chem 111: 428-432.

25. Urbani P, A Ramunno, R Filosa, A Pinto, A Popolo et al. (2008) Antioxidant Activity of Diphenylpropion-Amide Derivatives: Synthesis, Biological Evaluation and Computational. Anal Molecules 13: 749-761.

26. Skehan P, Storeng R, Dominic S, Anne M, Mcmohan J et al. (1990) New Colorimetric Cytotoxicity Assay for Anti-Cancer Drug Screening. J Nat Cancer Inst 82: 1107-1112.

27. Fabregas J, Maseda A, Dominguez A, Otero A (2004) The Cell Composition of Nannochloropsis Sp Changes Under Different Irradiances in Semi Continuous Culture. World J Microbiol Biotechnol 20, 31-35.

28. Gordillo FJL, Niell FX, Figueroa FL (2001) Non-Photosynthetic Enhancement of Growth by High CO2 Level in The Nitrophilic Seaweed Ulva Rigida C Agardh (Chlorophyta). Planta 213: 64-70. 
Citation: Abd El Baky H, Hanaa El Baz KF, EL-Latife SA (2013) Induction of Sulfated Polysaccharides in Spirulina platensis as Response to Nitrogen Concentration and its Biological Evaluation. J Aquac Res Development 5: 206 doi:10.4172/2155-9546.1000206

Page 8 of 8

29. Vermaas, W. F. (2001). Photosynthesis and Respiration in Cyanobacteria. Ency-Clopedia of Life Sciences. 1-7.

30. Yeesang C, Cheirsilp B (2011) Effect of Nitrogen, Salt and Iron Content in the Growth Medium and Light Intensity on Lipid Production by Microalgae Isolated From Fresh Water Sources in Thailand. Bioresource Technol 102: 3034-3040.

31. Schaeffer DJ, Krylov VS (2000) Anti-HIV Activity of Extracts and Compounds from Algae and Cyanobacteria. Ecotoxi Environ Safety 45: 208-227.

32. Mao W, Zang X, Li Y, Zhang H (2006) Sulfated Polysaccharides From Marine Green Algae Ulva Conglobata And Their Anticoagulant Activity. J Appl Phyco 18, 9-14."

33. Yang J, Du Y, Huang R, Wan Y, Wen Y (2005) The Structure Anticoagulant Activity Relationships of Sulfated Lacquer Polysaccharide Effect of Carboxyl Group and Position of Sulfation. Inter J Biologi Macromolecules 36: 9-15.

34. Abd El-Baky, HH, El-Baz FK, El-Baroty GS (2009).Potential Biolo-Gical Properties of Sulphated Polysa-Ccharides Extracted From The Macroalgae Ulva Lactuca L. Acad J Cancer Research 2: 1-11.

35. Anderson RA, Feathergill KA, Diao XH, Cooper MD, Kirkpatrick R et al. (2002) Preclinical Evaluation of Sodium Cellulose Sulfate (Usher Cell) as a Contraceptive Antimicrobial Agent. J Andrology 23: 426-438.

36. Mendiola JA, Jaime L, Santoyo S, Reglero G, Cifuentes A, Ibañez E, Seoñráns FJ (2007) Screening of Functional Compounds in Supercritical Fluid Extracts From Spirulina platensis. Food Chem 102: 1357-1367.

37. Toshihiko T, Amornut C, Robert LJ (2003) Structure and Bioactivity of Sulfated Polysaccharides. Trend in Glycosci and Glycotechnol 5: 29-46.

38. Chirasuwan N, Chaiklahan R, Ruengjitchatchawalya M, Bunnag B, Tanticharoen M (2007) Anti HSV-1 Activity of Spirulina platensis PolysAccharide. Kasetsart J Nat Sci 41: 311-318.

39. El-Baroty G, Shallan M, Ali MA, Abd El-Baky HH, El-Baz FK, Shalaby EA (2005) Antiviral Activity Of Different Extracts From Spirulina Maxima. 3rd Conference on Recent Technologies in Agriculture, November 8-15:1-7.

40. Shanmugam M, Mody KH (2000) Heparinoid-Active Sulphated Polysaccharides From Marine Algae As Potential Anticoagulant Agents. Current Science, 79: 1672-1682.

41. Kaji T, Fujiwara Y, Inomata Y, Hamada C, Yamamoto C, Shimada S, Lee JB, Hayashi T (2002) Repair of Wounded Monolayers of Cultured Bovine
Aortic Endothelial Cells is Inhibited by Calcium Spirulan, A Novel Sulfated Polysaccharide Isolated From Spirulina platensis. Life Sci 70: 1841-1848.

42. Yang D, Wang Q, Ke L, Jiang J, Ying T (2007) Antioxidant Activities Of Various Extracts Of Lotus (Nelumbo Nuficera Gaertn) Rhizome. Asia Pac J Clin Nutr 16: 158-163.

43. Zhao X, Xue CH, Li ZJ, YP Cai, HY Liu Et Al., (2004) Antioxidant and Hepatoprotective Activities of Low Molecular Weight Sulfated Polysaccharide From Laminaria Japonica. J Appl Phyco 16: 111-115.

44. Rocha De Souza MC, Marques CT, Dore CMG, Ferrira Da Silva FR, Rocha HAO, Leite EL (2007) Antioxidant Activities of Sulfated Polysaccharides From Brown and Red Seaweeds. J Appl Phyco 19: 153-160.

45. Athukorala Y, Kim K, Jeon Y (2006) Antiproliferative and Antioxidant Properties of an Enzymatic Hydrolysate from Brown Algae Ecklonia Cava. Food Chem Toxicol 44: 1065-1074.

46. Kim IH, Lee JH (2008) Antimicrobial Activities Against Methicillin-Resistant Staphylococcus Aureus From Macroalgae. J Indus Engin Chem 14: 568-572.

47. Qi H, Zhang TQ, Li Z, Zhao Z ,Xing R (2005) Antioxidant Activity Of Different Molecular Weight Sulfated Polysaccharides From Ulva Lactucapertusa Kjellm (Chlorophyta). J Appl Phycol 17: 527-534.

48. Kwon M, Nam T (2007) A Polys-Accharide of The Marine Alga Capsosiphon Fulvescens Induces Apoptosis in AGS Gastric Cancer Cells Via An IGF-IRMediated PI3K/Akt Pathway. Cell Biol Int 31: 768-775.

49. Hui W, O Engchoon, PO Ang (2007) Antiviral Polysaccharide Isolated From Hong Kong Brown Seaweed Hydroclathrus Clathratus. Sci China Ser C Life Sci 50: 611-618.

50. Mundt S, S Kreitlow, R Jansen (2003) Fatty Acids with Antibacterial Activity from the Cyanobacterium Oscilla-Toria Redekei HUB 051. J Appl Phycol 15: 263-267.

51. Mazumder S, Ghosal KP, Pujol AC, Carlucci JM, Damonte BE et al. (2002) Isolation, Chemical Investigation and Antiviral Activity of Polysaccharides from Gracilaria Corticata (Gracilariceae, Rhodophyta). Inter J Biologi Macromol 31: 87-95.

52. Kolender AA, Motulewicz MC, Cerezo AS (1995) Structural Analysis of Antivira Sulfated A-D-(1---3)-Linked Mannans. Carbohyd Res 273: 179-185. 